\title{
The influence of non-governmental organizations (NGOs) on the development of voluntary sustainability accounting reporting rules
}

\author{
Seleshi Sisaye \\ Palumbo-Donahue School of Business, Duquesne University, \\ Pittsburgh, Pennsylvania, USA
}

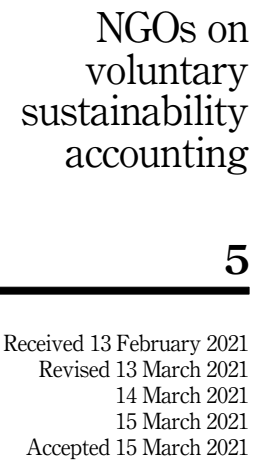

\begin{abstract}
Purpose - The purpose of this paper is to show the impact that non-governmental organizations (NGOs) have on the evolution of Global Reporting Initiative (GRI). GRI is a sustainability report disclosed by business organizations to meet the demands and interests of various stakeholders. These stakeholders' needs have influenced GRI and its guidelines.

Design/methodology/approach - The methodology for this paper is library-based archival research. It is qualitatively and analytically descriptive of prior academic research and published literature on the subject. Findings - Sustainability accounting rulemaking has evolved overtime resulting in proliferation of reporting rules. These rules have improved the extent and scope of environmental and economic performances that businesses disclose in GRI.

Originality/value - GRI has provided the foundation for integrated reporting (IR). Both GRI and IR have ecological and functional dimensions. Sustainability is functionally inherent in the accounting principle of materiality, when disclosed in external reporting. The ongoing concern of business assumes an organization is systemic and operates as a living entity only when it can provide sustainable performance that benefits stakeholders and society.
\end{abstract}

Keywords IR, GRI, CSR, Sustainability accounting, NGOs, Environmental management,

Socio-economic development

Paper type Research paper

\section{Introduction}

In business, sustainability encompasses all business enterprise systems, including the organization's strategic, legal, personnel and functional management areas. Sustainability responsibilities reflect the institutionalization of ecological programs and the corporate governance policies of business organizations. The sustainability accounting rulemaking process is an evolution shaped by corporate governance and external environmental factors including stakeholders. It is an ecological change brought from organizational and societal development.

(C) Seleshi Sisaye. Published in Journal of Business and Socio-economic Development. Published by Emerald Publishing Limited. This article is published under the Creative Commons Attribution (CC BY 4.0) licence. Anyone may reproduce, distribute, translate and create derivative works of this article (for both commercial and non-commercial purposes), subject to full attribution to the original publication and authors. The full terms of this licence may be seen at $\mathrm{http} / / /$ creativecommons.org/licences/by/4.0/legalcode

There is no funding for this paper.

The author greatly acknowledges the substantial comments of the two anonymous reviewers and the Editor of the journal. Their suggestions have improved the scope of the paper. The author assumes responsibility for the final product.

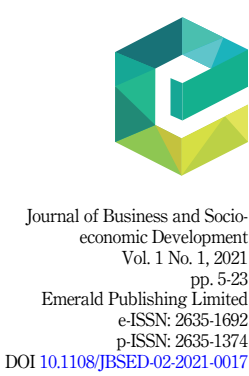


JBSED

1,1

Most studies in sustainability and corporate governance have limited coverage in sustainability science from the fields of sociology and anthropology. Bebbington and Larrinage (2014) suggested that sustainability is broad and examines the relationships between society and its environment, along with other natural systems (pp. 402-403). They stressed the need for an interdisciplinary approach to sustainability sciences, from the perspective of sociology and anthropology, that examines the fundamental questions of demography, culture, climate, ecosystems, history and political practices.

This paper fills the research gap in the accounting literature by incorporating the ecological framework from anthropology to study the history and development of the voluntary sustainability accounting rulemaking processes. The methodology for this paper is library-based archival research. It is theoretical and qualitative, and analytically descriptive of prior academic research and published literature on sustainability accounting and reporting.

\section{Contributions of the research/study}

The social and behavioral sciences approach to accounting research has largely focused on the application of economics and psychology theories. The sociology literature is recent, and primarily applied in critical, radical and interpretive studies of accounting issues. The application of the ecology anthropology framework is relatively absent in the accounting literature.

This paper is original in that it is the first study to apply the ecology framework to describe the process of accounting rulemaking. In doing so, it integrates the ecological, social and corporate governance frameworks to study the role of NGOs in the development of voluntary sustainability accounting rulemaking. Accordingly, there are three areas of research that this study can contribute to in the accounting and business management literature.

First, this study is unique in that it applies the stakeholder theory to integrate the ecological framework with the social and governance structures of business organizations. This study shows that the policies for the design and implementation of business sustainability are determined by ecological and environmental factors, corporate governance and responsibility, and organizational structures.

Second, this paper describes the evolution of sustainable development literature in anthropology and sociology. This review is significant because it highlights that sustainability has its foundations in the ecological anthropology of social soundness analysis (SSA) and the Brundtland et al. (1987) Report, sponsored by the United Nations Development Program (UNDP). The subsequent acceptance of sustainability and SSA by international development organizations (IDOs) led to programs focusing on environmental and natural resources conservation policies internationally. NGOs, among whose members are IDOs, have advocated for environmental legislation and natural resources conservation and management programs. This advocacy has been reflected in the standardization of environmental and social reporting in corporate social reporting (CSR), Global Reporting Initiative (GRI) and integrated reporting (IR) reports for member corporations.

Third, this paper is the first study to use the ecological framework to show that sustainability accounting has not yet materialized due to the ecology of rulemaking and the bureaucratization of accounting rules. This approach has not been widely applied in accounting research but shows that sustainable accounting rulemaking can only be achieved when rules are bureaucratized and codified by accounting standard setting organizations.

\section{Organization of the paper}

The paper is organized into five sections. Section one introduces the background of sustainable development from the ecological framework, thereby providing the context for the emergence of sustainability accounting. This section also describes the link among 
ecology, business sustainability and corporate governance. The second section discusses stakeholder theory and corporate boards' diversity and governance structures. While a business organization has several external stakeholders, NGOS are the most prominent when it comes to the voluntary sustainability accounting rulemaking processes, as outlined in the GRI standards. The third section discusses the NGOs involved in outlining GRI's framework and traces the evolution and foundation of GRI in standardizing sustainability reporting.

The link between sustainability reporting and IR reports is detailed in section four. This section examines GRI and IR as significant outcomes due to NGOs influence on the sustainability reporting of business organizations. GRI paved the way for the standardization of sustainability reporting, along with its integration of IR by the International Integrated Reporting Council (IIRC). The fifth section is the conclusion. It discusses the future trends and prospects of including sustainability indicators of performance in GRI and IR. It highlights the prospects for the bureaucratization of sustainability accounting rulemaking.

\section{Section one: the evolution of sustainability accounting}

This section introduces the background for sustainability accounting and describes the historical context and theoretical framework of the ecology of sustainability.

\section{Historical context of sustainable development}

In this paper, sustainability is defined within the context of ecological anthropology and the Brundtland et al. (1987) Report. Sustainable development evolved in the social sciences, particularly in anthropology. Its primary focus was to make policy makers and donors aware of the developmental needs of low-income agrarian economies to overhaul their practices of sustainable agriculture and rural development (Hoben, 1982).

In 1987, the UNDP, which is headquartered in New York City, supported the Report of World Commission on Environment and Development (WCED) - Brundtland Commission Report. This report is the most noted sustainability report and gave credence to the importance and recognition of sustainability growth and development in least developed countries (LDC). The report defined sustainability as "the ability to meet the needs of present generations without compromising the ability of future generations to meet their own needs" (p. 8). It also outlined three principles of sustainable development: environmental integrity, social equity and economic prosperity (Bansal, 2005).

The Brundtland (1987) report recognized that humans are dependent on the environment to meet their needs. The well-being of society is dependent on the balance between ecology and economic growth, conservation and social equity. The report was well received by both industrialized and developing countries, as well as IDOs, and bilateral and multilateral organizations. NGOs supported the report due to its balanced growth programs for corporate sustainable performance (Lee, 2019). The report became the foundation for the national and international policies of sustainable development for business performances. It also singled out ecology as the primary lens to address sustainable environmental conservation policies.

\section{Theoretical framework: the ecology of anthropology and organizational change}

Sustainable development falls within the domain of ecology, which takes a deterministic approach, when specifying that environment shapes corporate governance structures. Environmental shifts lead to the development of new policies and procedures to maintain organizational stability and functional adaptation. The field of anthropology has noted the importance of environmental and natural resource conservation policies to counterbalance the consequences of industrial and urban development practices on traditional and agrarian societies. Anthropologists were involved in the planned development programs of bilateral 

JBSED
1,1

and multilateral organizations to promote social and economic growth in developing economies (Hoben, 1982). Ecological anthropology integrated slash and burn agriculture of traditional societies with local land management and farming practices as a sustainability framework for conservation policies in industrialized societies.

The ecological anthropology approach to sustainability was formulated in the SSA in the 1970s within the context of IDO's programs (Hoben, 1982). SSA, focused on sustainability, promotes aligning the needs of people with technological developments to minimize the effect of technology on altering/changing indigenous/local modes of living and social life. Kottack (1999) noted that the SSA approach to "sustainable development aims at culturally appropriate, ecologically sensitive, self-regenerating change" (p. 26). Ecologically, the success of sustainability depended whether synergy exists between economic development programs and existing cultural practices (Stone, 2003).

The principles of SSA were endorsed in the Brundtland (1987) Report and by IDOs. International organizations captured the essence of this report and diffused it in their development assistance projects in LDCs. Corporations followed by incorporating sustainability into their business corporate policies. New accounting techniques, GRI and $\mathrm{IR}$, evolved to record and disclose corporate sustainability performance.

\section{Sustainability accounting: the birth of new rules}

Accounting innovations are outcomes of organizational growth, development and transformation processes (Sisaye and Birnberg, 2014). As organizations evolve over time, they create accounting mechanisms that, among other purposes, serve to maintain functional stability and performance. Evolutionary processes require structural and systemic developments, resulting in transformational changes. These changes overhaul the existing accounting rules and regulations by giving birth to new accounting rules and procedures.

Organizations develop new accounting rules only when they are necessary to address "new problems that do not seem to be covered by existing rules and when these problems are fairly recurrent, consequential or salient" (Schultz, 1998, p. 845). This allows the organization to retain what has been learned from past experiences in the form of "codified" rules and regulations, resulting in bureaucratization (Schultz, 1998). Accounting rule changes may be initiated by policy makers and/or stakeholders.

Sustainability accounting is an accounting innovation and an outcome of the organizational change process. As organizations face increasing demands from their constituencies for transparency, they adopt innovation to develop new avenues to disclose information to these constituencies (Ringel et al., 2018). NGOs are important stakeholders and indirectly influence rules change in accounting through lobbying and meeting with policy makers who are involved in the accounting rulemaking and regulations process. This evolutionary process to restructure and change current rules is incremental, necessitating the birth of new accounting rules. Sustainability accounting and reporting are these new rules but have yet to be bureaucratized.

Sustainability accounting can be broadly defined as a business organization strategy that links businesses with their organizations' external and internal ecological environments. The interaction between business and production economies is recorded and reported in a company's activities for economic, social and environmental performance (AICPA, 2021). The accounting framework provides guidelines to ensure that sustainability is embedded into an organization's day-to-day operations to evaluate the risks and opportunities associated with the implementation of sustainable strategies.

The concept of sustainability accounting is related to sustainability management and reporting. It has been broadly interpreted to denote sustainable cost, natural capital inventory accounting, input-output analysis, full cost accounting, triple bottom line 
reporting (TBL) and IR (for details, refer to Bebbington et al., 2001; Burritt and Schaltegger, 2010; de Villiers et al., 2014; Gary et al., 2011; Lamberton, 2005; and Schaltegger et al., 2017). Sustainability has been reported in GRI, CSR, TBL and IR. These reports are interrelated, as the ecology of sustainability accounting is broader than and inclusive of all these reports. Ecology incorporates corporate governance responsibilities, which is necessary when meeting sustainability accounting practices of environmental, social and economic performances, and then disclosing them in these reports.

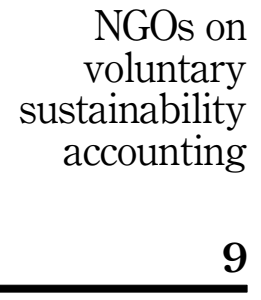

The ecology of corporate governance approaches to sustainability accounting

There are several theories, including legitimacy, agency and institutional, that have examined the impact of stakeholders on business sustainability. However, this paper focuses on ecological and corporate governance aspects of stakeholder theory. This is because, as Summerhays and de Villiers (2012) have noted, stakeholder pressure is intensified following incidents, such as major oil spills, which affect social and environmental well-being. This suggests that ecological concerns are in the forefront of both stakeholders and corporations. Accordingly, the influence of external stakeholders on business sustainability is shaped by ecological concerns and corporate governance structures.

Ecology embodies stakeholder theory along with corporate governance structures, firm and industry characteristics, and geographical location (country affiliation), which helps determine the use and practice of sustainability accounting and reporting. Stakeholder demands for social and environmental information have caused companies to document their sustainable performance. Subsequently, several sustainability guidelines were promulgated to improve sustainability accounting and reporting.

The history of sustainability accounting started in 1997 with the creation of GRI, and later with guidelines formulated in Johannesburg in 2002 at the World Summit on Sustainable Development (WSSD). IR was introduced in the King Code of Corporate Governance Principles III, as part of corporate governance reforms in South Africa (de Villiers et al., 2017). IR is now accepted in many European countries.

Corporate responsibility refers to the ethical and social values that organizations must have to provide sustainable products and services that are beneficial to the environment and society at large. This responsibility includes governance policies to promote sustainable social and economic development (Kanjia and Choprab, 2010). The ecological framework integrates both external environmental and internal aspects of corporate governance, as well as sustainability accounting and reporting. Political systems and corporate board governing structures are shaped by ecological variations, which can affect the degree to which stakeholders are able to influence corporate environmental policies (Fuente et al., 2017 and Haque and Jones, 2020).

\section{Section two: the stakeholder view of business sustainability}

The ecological framework examines both the internal and external orientations of sustainability. The external approach is related to the stakeholder theory, whereas the internal approach addresses corporate governance aspects of organizational management. Ecology is the determinant force in shaping sustainability accounting and reporting.

Stakeholder theory assumes that business organizations have several stakeholders besides stockholders, including employees and customers: both institutional and individual; the local community; creditors; government regulatory organizations and/or agencies; public interest groups; environmental groups; trade associations; and competitors, including NGOs (Banerjee, 2002; and Harangozo and Zilalhy, 2015). Corporate policies and structure determine the extent to which stakeholders are involved in business sustainability. 
$\underset{1,1}{\text { JBSED }}$

The ecology of corporate social and structural governances and board of directors diversity on sustainability

The external environmental orientation of business organizations is to manage stakeholders, which is an important aspect of corporate governance structure. According to Kanjia and Choprab (2010), "corporate governance refers to the broad range of policies and practices that stockholders, executive managers and boards of directors use to: (1) manage themselves; and (2) fulfil their responsibilities to investors and other stakeholders" (p. 125). However, the extent to which stakeholders are involved in corporate activities depends on ecological factors, which vary by country. For example, a country's political systems, two vs multi parties; presidential or parliamentary systems; and the existence of democratic or monarchical or dictatorial institutions, determine corporate ownership structures, systems, rules and institutional governances.

Corporate sustainability is a broader strategic plan that links corporate governance structure to strategies that embrace ownership of corporate sustainability that aligns sustainability goals with business indicators of long-term improved performance (Salvioni and Gennari, 2016). Corporations that have adopted these sustainability practices have a competitive advantage over others in their industry. Sustainability practices empower corporations to implement strategies and commitments that balance long-term economic growth and social development.

The diffusion of sustainability and corporate social responsibility practices are worldwide, but differences exist among the European and North American countries (Taliento et al., 2019). Corporations have a board of directors that is elected and/or appointed from both inside and outside the corporation. While there are variations in the relative influence of board members among countries, they all are accountable for corporate sustainability performance.

\section{Corporate board composition diversity and sustainability performance disclosures}

Corporate board composition and structures and external practices affect the implementation of sustainability practices (Post et al., 2011). Corporate board diversity in terms of sex (Glass et al., 2015), generational age differences (Ferrero-Ferrero et al., 2015) and external organizational stakeholder orientation practices (Post et al., 2011) shape whether stockholder engagement will impact the quality of sustainable information disclosed in CSR and GRI reports in European countries.

Fuente et al. (2017) and Haque and Jones (2020) reported an association between the diversity of corporate boards and the disclosure of sustainability information. They asserted that a board with a higher proportion of female members and the relative degree of directorial independence was associated with increased disclosures. Moreover, if corporations have the functional existence of an independent committee or directors or task force specifically assigned for CSR, there is an impact on the dissemination of sustainability information. Haque and Jones (2020) documented that the increased disclosure of biodiversity initiatives (DBI) and biodiversity impact assessments (BIA) associated with gender diversity was related to increased proportion of female corporate board members. In general, NGO stakeholders have impacted corporate environmental policies and sustainability performances.

\section{Effect of NGOs on corporate environmental sustainability}

NGOs are "legitimate partners" of business organizations (Banerjee, 2002, p. 179). They have long partnered with multinational corporations (MNCs) to address civil and environmental issues and increase civilian participation in business sustainability performance (Harangozo and Zilahy, 2015). They help mitigate the impact of economic growth on the environment 
through public lobbying and serving as members of the board for MNCs (Lee, 2019). They also lobby policy makers and regulatory agencies to enact legislation.

NGOs employ cooperative strategies to solicit business responsiveness. Harangozo and Zilahy (2015) saw cooperation strategy as beneficial because it enlists engagement, participation, dialogue and the enactment of voluntary measures that are beneficial to promote partnership and future commitment for sustainable programs. That is, enhanced interactions between NGOs and MNCs facilitate the development of legislation and accounting rules for sustainability performance.

Lee (2019) discussed how the cooperative policies of environmental non-governmental organizations (ENGOs) mitigated the negative effects of corporations' environmental programs. ENGOs form alliances by partnering their activities with policy makers as advisory groups, and by making the public aware, through media and other outlets, that they make corporations responsive and commit to the future by enacting programs that protect the environment. These partnerships and subsequent cooperation have resulted in environmental legislation and sustainability reporting guidelines in GRI (Moratis and Brandt, 2017; Grushina, 2016). Corporations can address business environment sustainability performance through civil participation with limited litigation and confrontation (ElAlfy, 2020; Harangozo and Zilahy 2015).

Corporations as functional systems pursue strategies to meet the demands of their powerful institutional stakeholders. NGOs exert pressure for environmental policies that affect their constituencies. However, as Rudel et al. (2011) suggested, environmental policies occur in a series of steps over time, and the legislation of these policies requires a long-time horizon. While organizations are adaptive systems, the dynamics for survival and stability make it necessary to establish working relations with their stakeholders. Organizations modify existing accounting policies and structures to respond to changes in the external environmental constituencies including stakeholders. These developments gave birth to sustainability accounting rules.

GRI and IR resulted from accounting innovations in sustainability rules and procedures. However, as these guidelines are still voluntary, they are not yet mandated by accounting policy makers. Nevertheless, many business organizations use GRI or IR to disclose environmental and social performance to their stakeholders.

\section{Section three: NGOs and the formalization of sustainability reporting}

The NGOs that have impacted voluntary sustainability reporting guidelines are the IDOs and multilateral international organizations. GRI and IR are outcomes of IDO's involvement in the development of standardized sustainability accounting guidelines for corporate reporting. GRI has its underlying framework in the Brundtland Report (1987).

\section{The Brundtland (1987) report: IDO multilateral and bilateral organizations and GRI's background}

The Brundtland Commission (1987) report outlined a "macro" or national/international approach-solution to the world's economic-social-and-environmental challenges in the twenty-first century. The report highlighted the importance of ecological anthropology in sustainable development. The report also encouraged government, IDOs and business organizations to envision a future in which the threats of environmental destruction are minimized and the people of the world benefit from economic stability and social equity.

The Brundtland Report (1987) sustainability development framework was endorsed by multilateral organizations. The World Business Council for Sustainable Development (WBCSD), the International Auditing and Assurance Board (IAASB), the International 

JBSED
1,1

Labour Organization (ILO), the United Nations Global Compact (UNGC), the International Organization for Standardization (ISO) and the GRI embedded sustainability as the underlying framework for GRI. These IDO, as described below, are the early pioneers of social and environmental sustainability accounting.

\section{The International Organization for Standardization (ISO)}

The European Union (EU), with its expanding membership, needed to unite its members' corporate standards and the world business organizations' standards, in a single quality standard to coordinate international commerce and trade. In 1987, the EU devised a set of standards called the ISO. The ISO 9000 outlined a set of procedures, guidelines and standards for companies to adhere to when conducting business with EU nations. The ISO 9000 certification incorporated a set of standards governing documentation, work instructions and record keeping. Taken together, this set of standards have resulted in an ISO certification by qualified external examiner, such as the public accounting firms (ISO, 2021). Once certified, companies are listed in a directory for potential memberships in European and world-wide business organizations.

The ILO supported the ISO 9000 certification, which developed a set of procedures, guidelines and standards for MNCs to adhere to when working to improve labor standards and protection, equal pay and workers' rights (including child labor and safe working conditions) and anti-corruption (ILO, 2006 and 2007). It required companies to provide documentation showing that they developed record keeping systems as required for ISO certification. The certification became the standard by which to recognize quality products and services that have met ILO guidelines on labor safety and working conditions (ILO, 2021).

ISO 9000 became one of the first quality standard guidelines recognized around the world. As of 2007, there were over 600,000 certifications awarded to companies in 158 countries (ISO, 2020a, b). The ISO 9000 was revised in 2015 to ISO 9001. By 2021, there are over one million companies and organizations in over 170 countries certified to ISO 9001 (ISO, 2021). With the widespread adoption of the ISO 9000 certification, there came increasing concern about the world's depletion of natural resources and the environmental risks associated with the globalization of businesses.

The ISO responded to this concern by creating the ISO 14000 and 14,001 (ISO, 2021). The ILO later revised and introduced ISO 14000 for environmental management systems documentation, which addressed the world's depletion of natural resources and the environmental risks associated with industrialization. It required participating companies to keep track of raw materials usage, including the generation, treatment and disposal of their hazardous wastes; emission control; and continuous improvement plans. It set guidelines on pollution emissions and required companies to prepare ongoing improvement plans in their environmental performance (ILO, 2021).

The ISO 14001 Certifications that followed elaborated the advantages of sustainability ranging from corporate mandates to regulatory considerations, and subsequently to environmental benefits. It provided the framework for members' business organizations to satisfy and fulfill external requirements related to customers; improve relationships with governmental agencies; improve stakeholder responsibility, positive publicity, and competitive advantage; and reduced insurance premiums (ILO and ISO, 2020).

Through Global Compact's Communication on Progress (COP), a policy that promoted transparency and accountability, participating companies were encouraged to provide annual postings. They were required to adhere to policies of transparency and full disclosure. If these companies failed to abide by these policies, they were sanctioned by changing their status from participating members to possibly "delisting" them by excluding their names from the directory. The Global Compact guidelines and policies assisted the private sector in managing and minimizing potential risks associated with their business conduct. 
It encouraged environmental and social governance; and advocated embedding markets and societies with universal humanitarian and societal principles for the benefits of all stakeholders and the community at large.

\section{The International Labour Organization (ILO)}

The ILO, headquartered in Hague, The Netherlands, adopted in 1998 the International Fair Practice Employment and Labor Standards as part of its sustainability development efforts for child labor protection and equal pay for equal work initiatives in the developing world. In support of the ISO, it endorsed the UNGC (UNGC, 2020a, b), a strategic policy initiative in which businesses commit to aligning their operations and strategies to four sustainability objectives: human rights, safe working conditions, environmental protection and mitigation procedures against corruption.

\section{The United Nations Global Compact (UNGC)}

The UNGC is a public-private strategic initiative endorsed by the United Nations (UN) in 1999. It is a policy framework for the development, implementation and disclosure of sustainability principles and practices. It offers participants a wide spectrum of specialized work streams, management tools and resources, and topical programs and projects. These are all designed to help advance sustainable business models and markets and contribute to the initiative's overarching mission of helping build a more sustainable and inclusive global economy. Although the initiative is voluntary, it has emphasized the importance of corporate accountability and the benefits of engagement among all participants and stakeholders (UNGC, 2020a, b; Oizes et al., 2020).

The UN in 2000 adopted the UNGC's four strategic policy principles: (1) The Universal Declaration of Human Rights, (2) The ILO's Declaration of Fundamental Principles and Rights at Work, (3) The Rio de Janeiro Declaration on Environment and Development and (4) The UNConvention against Corruption. These guidelines encouraged companies to embrace, support and enact, within their sphere of influence, a set of core values in the areas of human rights, labor standards, the environment and anti-corruption as part of the UN Global Compact's ten universally accepted principles (UNGC, 2020b). The UNG considered businesses the primary agents of global markets, commerce, technology and finance that promote sustainable economies, which benefit societies everywhere (UNGC, 2020a, b); Oizes et al., 2020). It stated that the objectives of the international community and the business world should be aligned around the common goals of building markets, combating corruption, safeguarding the environment and ensuring social inclusion.

UNGC initiatives increased memberships, partnerships and opened communications among businesses, government, civil society, labor and the UN. With over 12,000 corporate participants and other stakeholders from over 145 countries, the UNGC is the largest voluntary corporate responsibility initiative in the world, endorsed by Chief Executive Officers of corporations. The UNGC became the standard for the development, implementation and disclosure of sustainability policies and practices. It offers its participants a wide spectrum of work streams, management tools and resources to help advance sustainable business models and markets. The UNGC worked toward the vision of a sustainable, inclusive, global economy which delivers lasting benefits to people, communities and markets (UNGC, 2020a, b).

These initiatives were later incorporated in the GRI reports. GRI sets the framework for sustainability reporting, as corporations can systematically disclose their economic, environmental and social material information and impacts in an integrated report. These reports can assist in uniformly comparing sustainability information disclosures. The influence of NGOs on these voluntary sustainability accounting rules has been functional and

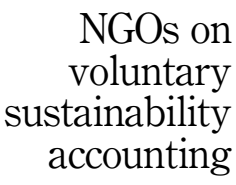

13 
JBSED

1,1

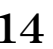

purposive. GRI reporting standards are the result of NGOs involvement in sustainability rulemaking. Nevertheless, the rules and guidelines of sustainability are continuously revised as evidenced in GRI, to respond to external environmental factors, including stakeholders. The accounting rulemaking for institutionalizing sustainability is still evolving, and continually changing, as evidenced in the revision of the GRI guidelines overtime.

\section{Section four: GRI and sustainability reporting}

GRI was launched in 1997. Its founders wanted to have general guidelines for social and environmental indicators of corporate sustainability performance to compare across industries (Reid, 2013). GRI followed the reporting guidelines established in the United States by the Financial Accounting Standards Board (FASB) (FASB, 2020). FASB developed a standardized voluntary approach to reporting on corporate financial, environmental and social performance to increase interest and demand for sustainability data and information.

\section{The foundation of GRI}

In the late 1970s, the United Nations Environmental Program (UNEP) worked cooperatively with the Coalition for Environmentally Responsible EconomieS (CERES) and the TELLUS Institute. CERES is a not-for-profit organization founded in 1989 and dedicated to transforming the world economy for a better sustainable future that protects the environment and the people. The goal was to promote stakeholder engagement and global advocacy for state, national and international regulatory and voluntary actions for balanced growth (CERES, 2021). TELLUS, which was established as a non-for-profit organizations (NFPs) in 1976, conducted research and developed policy guidelines addressing global and national environmental issues, climate change, corporate responsibility and sustainable development (TELLUS, 2021). The joint effort of UNEP, CERES and TELLUS provided guidance and support for the creation of GRI in 1997 (see Figure 1).

GRI has global strategic partnerships with the Organization for Economic Co-operation and Development (OECD), UNEP and UNGC. Its framework synthesizes guidance from the International Finance Corporations (IFC), ISO 26000, the United Nations Conference on Trade and Development (UNCTD) and the Earth Charter Initiative (ECI) (GRI, 2021a, b). The evolution of sustainability accounting and the dates of GRI guidelines are presented in Table 1.

\section{GRI guidelines and the evolution of sustainability reporting}

The GRI Sustainability Reporting Guidelines (SRG) of the GRI are developed by the Global Sustainability Standards Board (GSSB), in consultation with member organizations who are represented by a consortium of public accounting firms, financial consortia and internationally known MNCs (see Figure 1). To ensure acceptance and adoption, the board consists of global multi-stakeholders representatives from business, labor, civil society and financial markets. Moreover, auditors and experts in various fields, along with regulators and governmental agencies from several countries, are involved in the preparation of those guidelines. Accordingly, GRI policies are aligned with these international organizations initiatives and sustainable development policies. GRI has become the world leader and largest producer of standards/guidelines for reporting ecological "footprints" in sustainability (UNGC, 2020a, b).

GRI Sustainability Reporting Guidelines was first introduced in 2000, with subsequent amendments in 2002 and 2006. These guidelines consist of universal and topic-specific standards: core reporting principles (GRI 100); general disclosures designed to provide context about an organization (GRI 102); and guidance on dealing with material issues, which are managed and reported on using topic-specific standards (GRI 103). Disclosures are 

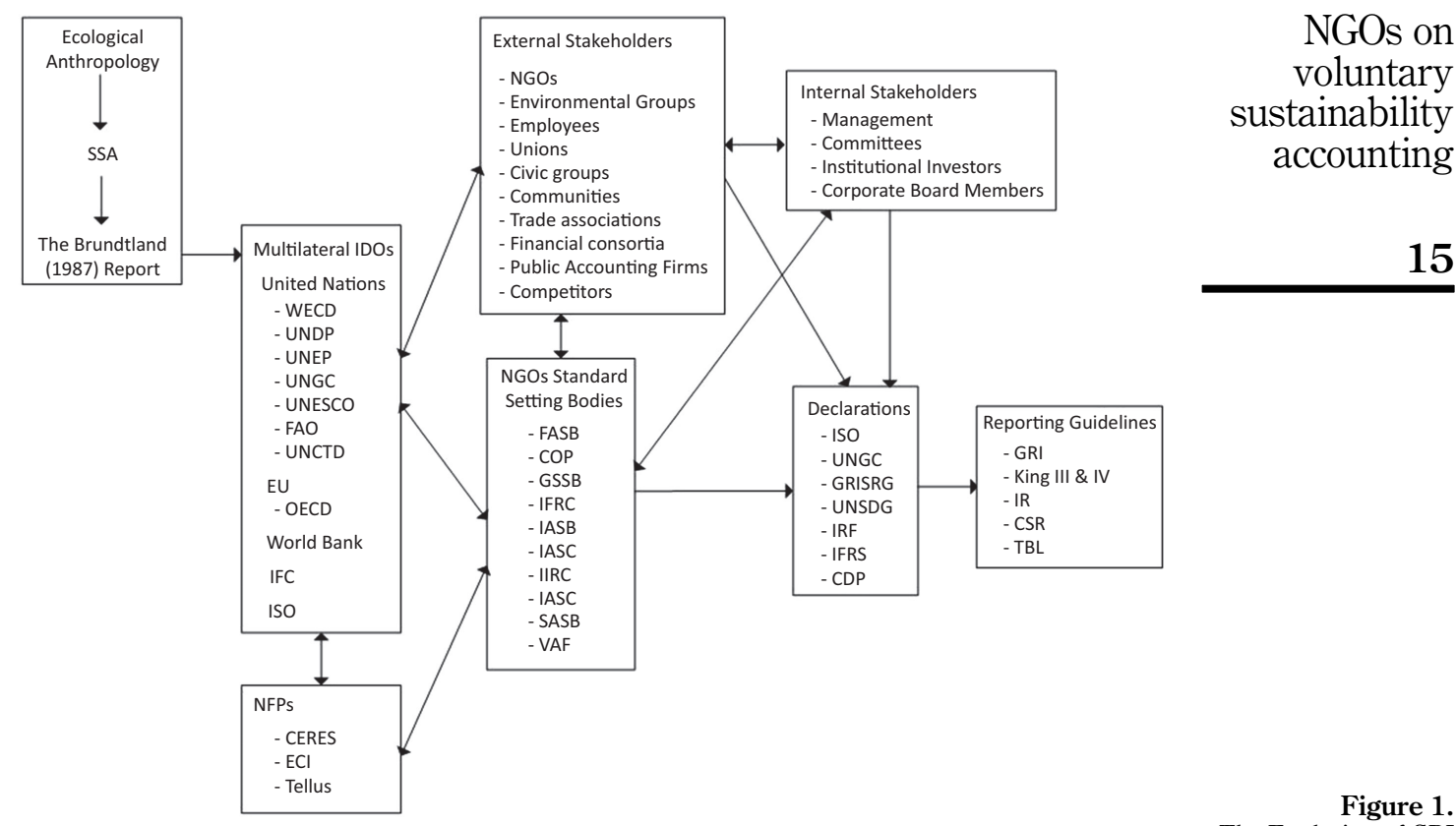

Figure 1. The Evolution of GRI

complemented by applicable economic (GRI200), environmental (GRI300) and social (GRI400), tax (GRI 207), water resources (GRI 303), waste (GRI 306), occupational, health and safety (OHS) (GRI 403) and other issues (see GRI, 2021c, and Table 1).

GRI identified three broad reporting areas: (1) organizational performance, (2) public policies and implementation measures and (3) the environmental context/state (see GRI, 2021a, b, and c). In 2004 the GRI-G3 application disclosure on organizational performances consisted of: (1) Organizational Profile, (2) Management Approach and (3) PerformanceRelated Indicators. In 2013, GRI issued G4 Sustainability Reporting Guidelines (GRI, 2021a, b). GRI G3 and G4 became the most widely used by MNCs, governments, small and medium enterprises, NGOs and industry groups in more than 90 countries.

The GRI guidelines require member organizations that have used GRI's sustainability reporting guidelines (SRG) as the basis for their report to either: (1) notify GRI upon release of their report and provide them with a copy, (2) register their report on GRI's online reporting database or (3) request that GRI check their self-declared application levels. Although such reporting is voluntary, the organizations that follow these guidelines have benefited by achieving continuous organizational improvements over time and have communicated those performance indicators to their stakeholders (Christofi et al., 2012; and GRI, 2021a, b). These reports provide comparable and uniform disclosure of sustainability social and environmental performance of business organizations. They have thus become the primary mode of communication with the various stakeholders of the business, including NGOs.

\section{The adoption and diffusion of GRI reporting guidelines}

GRI sustainable performance guidelines (GRI, 2021c) have been widely adopted. In 2017,63\% of the largest 100 companies and $75 \%$ of the Global Fortune 250 reported applying the GRI 


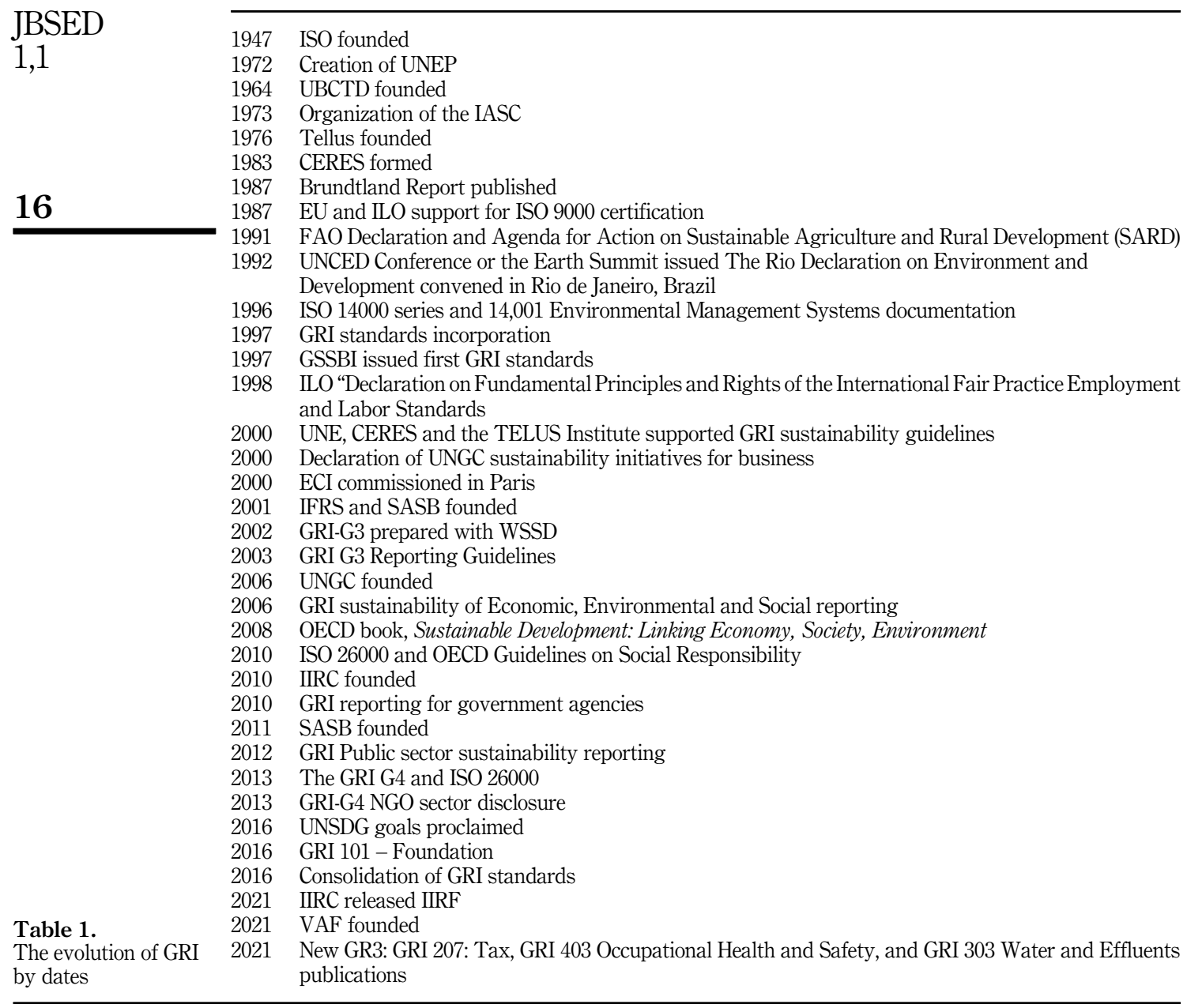

reporting framework (GRI Resource Center, 2021). Several studies have documented GRI's widespread.

Nikolaeva and Bicho (2011) noted that there is institutional pressure to adopt GRI for competitive purposes and the desire to seek legitimacy and become reputable (pp. 136-140). They emphasized the role of the media in publicizing good corporate practices and serving, at the same time, as a watchdog by exposing corporate unsustainable practices. The media has helped speed up the adoption of GRI, by giving it media coverage, publicity and exposure.

Grushina (2016) examined GRI's specifications of stakeholder engagement and found that sustainability reporting has been institutionalized as a form of organizational communication to obtain stakeholder collaboration in the organization's business activities. Moratis and Brandt (2017) investigated quality of stakeholder engagement (SE) within sustainability reporting (SR) from sustainability reports issued by European firms that adopted GRI's G4 Guidelines for CSR reporting. While they discovered disparities among corporations in their SE disclosures and SE quality of disclosed information, they found that in general GRI 
provided information on how corporations responded to stakeholder concerns and engaged with them to address them. The adoption of SE in GRI reports enabled interested stakeholders to easily compare disclosures due to the uniformity of these reports.

\section{GRI and CSR attributes for reporting business performances}

Several studies have documented that GRI and CSR provide qualitative information on business performance. CSR is incorporated in GRI standards for sustainable development programs advocated by the United Nations. ElAlfy (2020) studied the impact of the United Nations Sustainable Development Goals (UNSDG) and CSR research. The UNSDG has seventeen sustainable goals, including climate action, affordable and clean energy, clean water and sanitation, and sustainable cities and communities (UNSDG, 2021). They found a synergy between UNSDG and CSR and argued that these synergies contribute to better understanding global climate goals and how businesses are addressing them to accomplish their long-term performance objectives.

Rudel et al. (2011) noted that business organizations have adopted ecological modernization policies to counterbalance environmental mobilization of interest groups and government policies of protection and conservation. Perez et al. (2017) studied environmental disclosure by developing a reputation index of stakeholders' power, legitimacy and urgency and the link to CSR reports in meeting stakeholders demands. They examined 84 Spanish companies and found that power and legitimacy gave stakeholders the ability to monitor the information in CSR. However, as urgency was not related to the intensity of information provided to stakeholders, they affirmed that power and legitimacy gave stockholders the ability to influence the details of sustainability information disclosed in CSR.

Both GRI and CSR have multiple functional roles in dealing with their stakeholders and constituents. First, from a public relations viewpoint, CSR reports are effective in increasing stakeholder's proactiveness, engagement and interest in a corporation's business performance and social responsibility goals (Lim and Greenwood, 2017). Second, although there are variations in the level of environmental performance disclosures by industrial sectors, corporations who have adopted GRI have an external orientation whereby they disclose a wide range of information in their CSR reports (Cappuyns et al., 2015). Third, both GRI and CSR have internal orientations that are functional and purposive for systems maintenance and adaptation. Sustainability values and principles have ecological dimensions that shape organizations' strategic plans, missions, and policies. The multifacets of sustainability found in GRI and CSR are incorporated in the IR financial accounting framework.

\section{The evolution of IR: the inclusion of sustainability information}

IR dates its history back to the King Report on Corporate Governance in South Africa in the 1990s. The report contained sets of guidelines for the governance structures and operation of companies in South Africa. It was issued by the King Committee on Corporate Governance. Three reports were issued in 1994 (King I), 2002 (King II) and 2009 (King III) with a fourth revision (King IV) in 2016 (KPMG, 2021). The King III guidelines of IR in South Africa focused on CSR and were required of companies that listed in the Johannesburg Stock Exchange (JSE) (de Villiers et al., 2017). Solomon and Maroun (2012) found that the King III framework has resulted in an increased amount of social and environmental information in annual reports.

The King III Report laid the foundation for the creation of the IIRC in 2010 by the Prince of Wales Accounting for Sustainability Project (PWASP) (de Villiers et al., 2017). IR is the result of the efforts by IIRC, the Integrated Reporting Committee of South Africa (IRCSA), the World Business Council for Sustainable Development (WBCSD), the World Resources Institute 

JBSED
1,1

(WRI), the Carbon Disclosure Project (CDP), the UNGC and GRI. IR is the most recent development in sustainability reporting (de Villiers et al., 2017).

In 2013, the IIRC developed general guidelines for IR for disclosing social and environmental information that can create future long-term value for owners and stakeholders during an organization's life cycle. These guidelines were revised in January 2021. The revisions framed the overall objectives as creating capital and increasing the wealth of organizations to benefit the owners and society-at-large. It focused on financial, intellectual, human/social and natural environmental performance to create wealth. It developed a general framework of sustainability thinking and decision making for organizations' strategy, governance and growth that is integrated with the external environmental factors and the society-at-large (IFRC, 2021).

The accounting standards for IR have evolved over time. The International Financial Reporting Standards (IFRS) was established in 2001, which in time formed the International Accounting Standards Board (IASB). The IASB replaced the International Accounting Standards Committee (IASC), which was founded in 1973 (IASC, 2021). The IASB Board is the standard-setting body responsible for the preparation, development and publication of internationally recognized and accepted IFRS standards (IASB, 2021). These standards aim to promote transparency, accountability and global financial markets efficiency (IIIRC, 2021a).

The IIRC released in January 2021 the International Integrated Reporting Framework (IIRF) (IIRC, 2021b) to guide the preparation of integrated reports. The guidelines focused on four areas: improving the quality of information; promoting cohesive and efficient approaches to corporate reporting; enhancing accountability and stewardship; and encouraging integrated thinking, and decision making to address the shortcomings found in current accounting systems (IIRC, 2021b).

In the United States, an organization parallel to the IIRC, the Sustainability Accounting Standards Board (SASB), was founded in 2011 (SASB, 2021). Its mission focused on developing sustainability accounting standards for financial, environmental and social performance and corporate governance. In November 2020, SASB and IIRC announced their plan to merge into one organization - the Value Reporting Foundation (VAF). The objective of the merger is to simplify corporate sustainability reporting in both Western European countries and the United States. They plan to develop a comprehensive reporting framework long demanded by investors and corporations (Tho, 2021). This development has potential policy implications for the future of sustainability accounting and reporting.

\section{IR: the current frontier for corporate sustainability reporting}

IR is now the current frontier in corporate reporting, as it introduces an alternative perspective into the traditional economic notion of profit maximization by encouraging the assessment of corporate success based on an organization's ability to create sustainable value. de Villiers et al. (2017) viewed IR as being more systemic and holistic since it included the inter-connection of several factors affecting a business enterprise, including financial, environmental, social, cultural, corporate control and management and stakeholders' governance issues (see also Gary et al. (2011)).

Burritt and Schaltegger (2010) have listed four qualitative indicators of environmental management activities needed to make sustainability environmental performance reporting part of IR for an integrated business enterprise system. First, environmental reporting can facilitate compliance. Second, it aids in the implementation of policies and regulations and assists in the management of continuous improvement programs. Third, these reports generate data for decision making. Fourth, they produce external reports (p. 842). They referred to the first three indicators as having an internal orientation, with the fourth having an external focus. IR's overall objective is to make corporate disclosures a more effective means of communication by improving efficiency in management and investment decision 
making. IR's sustainability reporting has a broader framework in terms of its target audience, information content and focus on disclosing strategic and forward-looking information (de Villiers et al., 2014). These studies suggest that IR is associated with the continuous developments in non-financial measurement systems and reporting frameworks.

The IR approach is ecological, and its view of sustainability focuses on the interconnections of the environment with society and the economy. The IR environmental sustainability disclosures address the business enterprise environment, which comprises ecosystems, and natural resources including air, water and other non-renewable resources. When corporations document their strategic vision of environmental and social responsibilities in external reports, this integrated approach can result in a more successful sustainable value for business and society.

The IR framework is used throughout Europe, Australia, Asia and Africa, particularly South Africa. Jensen and Berg (2012) indicated that IR companies are more likely to come from countries with market-based economies, diversified ownership structure, a labor force with a union composition and a government political structure that is responsive to CSR. These reports are effective in holding shareholders accountable and help manage sustainability risks related to climate change and environmental issues. Serafeim (2015) argued that in corporations where investors have active interest in sustainable information, IR's long-term approach helps create value and business growth opportunities. The IR approach resulted in an inclusive sustainable report for financial, social and environmental information.

The history of GRI and IR suggests that the multiple goals of sustainability require managers to pursue innovative strategies of accounting rules in which change is integrative and systemic. A GRI and IR accounting reporting system is systemic, and functionally oriented to adapt to and modify existing reporting systems that align to the three interrelated areas of financial, environmental and social performance of the organization. Sustainability and materiality of GRI and IR make the organization functional, as it has characteristics of both an enduring and a living entity (i.e. growing concern) that is focused on continuous growth and development strategies.

\section{Section five: conclusion}

The research on social and environmental accounting and reporting suggests that both GRI and IR are in principle the same. Both have established the underlying standards for sustainable reporting guidelines. However, IR has a strategic, inclusive and continuous improvement orientation as its underlying reporting framework. It provides a systemic framework to address the business economic interests and organizations' stakeholder relationships (Schaltegger et al., 2017). IR followed GRI in establishing uniform and consistent reporting guidelines that increase the comparability and efficiency of information management on a detailed level.

NGOs are the primary stakeholders who have influenced the type of social and environmental information contained in GRI. However, most business organizations have not integrated these concerns in their external reports. They have rather included them in CSR as supplementary reports. CSR has been essential to disseminate sustainability information to corporate stakeholders.

The history of GRI suggests that there is an evolution of sustainability accounting rulemaking that is in process. This will eventually result in the proliferation of accounting rules to establish the foundation for an IR reporting system of sustainability and economic performance. The GRI evolution of sustainability accounting is functional to meet the internal and external orientation of business organizations. It addresses performance indicators, assists with compliance, sets specific targeted goals and enables linking the business and environmental goals of the organizations and society at-large. Therefore, when corporations incrementally improve their sustainability accounting reporting formats, they receive public 
JBSED

1,1

acceptance and favorable media coverage, and a reduction in compliance and externalities costs associated with government regulatory organizations.

The IFRS, IIRC and VAP are at the forefront of developing generally accepted sustainability reporting guidelines. The agenda for future research focuses on how the cooperation and involvement of NGOs and IDOs will materialize into accounting standard setting organizations that enact uniform reporting guidelines for sustainability accounting disclosures. If this manifest, it can significantly change the current voluntary use of sustainability guidelines and become the basis for mandatory reporting. While there are constraints and limitations in the development of sustainability accounting and reporting, the examples cited from European countries suggest that the prevalence of sustainability reporting guidelines in both GRI and IR.

Moreover, future research can examine sustainability accounting, IR and the question of how the inclusion of reporting, management control systems and assurances could be explained. Ecology could provide the framework to consider whether these factors could transform from voluntary to mandatory disclosures in financial reports. The policy implication that can be drawn from GRI and IR is that the evolution toward mandated accounting reporting guidelines is evident. However, when and how they are mandated is a subject of future research. When mandated, the ecology of sustainability accounting rulemaking regulates and bureaucratizes the procedures for enforcing compliance in external reporting.

\section{References}

American Institute of Certified Accountants (AICPA) (2021), Sustainability Accounting, AICPA, New York City, NY, available at: www.aicpa.org (accessed 5 March).

Banerjee, S.B. (2002), "Corporate environmentalism: the construct and its measurement”, Journal of Business Research, Vol. 55 No. 3, pp. 177-192.

Bansal, P. (2005), "Evolving sustainability: a longitudinal study of corporate sustainable development", Strategic Management Journal, Vol. 26 No. 3, pp. 197-218.

Bebbington, J. and Larrinaga, C. (2014), Accounting and sustainable development: an exploration, Accounting, Organizations and Society, Vol. 39, 6, pp. 395-413. S.

Bebbington, K.J., Gray, R.H., Hibbitt, C. and Kirk, E. (2001), Full Cost Accounting: An Agenda for Action, The Association of Chartered Certified Accountants (ACCA), London.

Brundtland Report, Chair, The World Commission on Environment and Development (1987), Our Common Future. The World Commission on Environment and Development (WCED), Oxford University Press, New York, NY.

Burritt, R.L. and Schaltegger, S. (2010), "Sustainability accounting and reporting: fad or trend", Accounting, Auditing \& Accountability Journal, Vol. 23 No. 7, pp. 829-846.

Cappuyns, V., Vandenbuclcke, C. and Ceulemans, K. (2015), "Economic and environmental performance indicators in Belgian GRI reports", Environmental Management and Sustainable Development, Vol. 4 No. 1, pp. 206-227.

Christofi, A., Christofi, P. and Sisaye, S. (2012), "Corporate sustainability: historical development and reporting practices", Management Research Review, Vol. 35 No. 2, pp. 157-172.

Coalition for Environmentally Responsible EconomieS (CERES) (2021), available at: https://www. ceres.org/about-us (accessed 24 February 2021).

de Villiers, C., Venter, E.R., Hsaio, P.C.K., Rinaldi, L. and Unerman, J. (2014), "Integrated reporting: insights, gaps and an agenda for future research", Accounting, Auditing \& Accountability Journal, Vol. 27 No. 7, pp. 1042-1067.

de Villiers, C., Venter, E.R. and Hsaio, P.C.K. (2017), "Integrated reporting: background, measurement issues, approaches and an agenda for future research", Accounting and Finance, Vol. 57 No. 4, pp. 937-959. 
ElAlfy, A. (2020), Redefining Strategic Corporate Social Responsibility (CSR) in the Sustainable Development Goals (SDGs) World, Unpublished Ph.D. dissertation, University of Waterloo, Ontario, Canada (accessed 8 October 2020).

Ferrero-Ferrero, I., Fernández-Izquierdo, M.A. and Muñoz-Torres, M.J. (2015), "Integrating sustainability into corporate governance: an empirical study on board diversity", Corporate Social Responsibility and Environmental Management, Vol. 22 No. 1, pp. 193-207.

Financial Accounting Standards Board (FASB) (2020), available at: https://www.fasb.org/home (accessed 23 October 2020).

Fuente, J.A., Garcia-Sanchez, I.M. and Lozano, M.B. (2017), "The role of the board of directors in the adoption of GRI guidelines for the disclosure of CSR information", Journal of Cleaner Production, Vol. 141 No. 10, pp. 737-750.

Gary, C.M., Fagerström, A. and Hassel, L.G. (2011), "Accounting for sustainability: what next? A research agenda", Annals of the University of Oradea, Economic Science Series Supplement, pp. 97-111.

Glass, C., Cook, A. and Ingersoll, A.R. (2015), "Do women leaders promote sustainability? Analyzing the effect of corporate governance composition on environmental performance", Business Strategy and the Environment, Vol. 25 No. 2, pp. 495-511.

Global Reporting Initiative (GRI) (2021a), GRI Sustainable Performance, available at: https://www. sustainable-performance.total.com/en/reporting/reporting-standards/global-reporting-initiativegri (accessed January 10).

Global Reporting Initiative (GRI) (2021b), available at: https:/www.globalreporting.org/about-gri/ (accessed January 11).

Global Reporting Initiative (GRI), Resource Center (2021c), available at: https://www.globalreporting. org/how-to- use-the-gri-standards/resource-center/ (accessed 9 January).

Grushina, S.V. (2016), "Collaboration by design: stakeholder engagement in GRI sustainability reporting guidelines", Organization and Environment, Vol. 30 No. 4, pp. 366-385.

Haque, F. and Jones, M.J. (2020), “European firms' corporate biodiversity disclosures and board gender diversity from 2002 to 2016", The British Accounting Review, Vol. 52 No. 2, pp. 68-73.

Harangozo, G. and Zilahy, G. (2015), "Cooperation between business and non-governmental organizations to promote sustainable development”, Journal of Cleaner Production, Vol. 8915 February, pp. 18-31.

Hoben, A. (1982), “Anthropologists and development”, Annual Review of Anthropology, Vol. 11, pp. 349-375.

International Accounting Standards Board (IASB) (2021), available at: https://www.ifrs.org/groups/ international-accounting-standards-board/ (accessed February 28).

International Accounting Standards Committee (IASC) (2021), available at: https://www.iasplus.com/ en/resources/ifrsf/history/resource25 (accessed February 28).

International Financial Reporting Standards (IFRS) (2021), available at: https://www.ifrs.org/usearound-the-world/why-global-accounting-standards/ (accessed February 28).

International Integrated Reporting Council (IIRC) (2021a), International $<I R>$ Framework $\mid$ Integrated Reporting, (accessed February 24).

International Integrated Reporting Council (IIRC) (2021b), available at: https://integratedreporting.org/ resource/international-ir-framework/ (accessed 3 March 2021).

International Labour Organization (ILO) (2006), "Socially sustainable development and participatory governance: legal and political aspects", in Papadakos, K. (Ed.), International Institute for Labour Studies, ILO, Geneva.

International Labour Organization (ILO) (2007), Decent Work for Sustainable Development: The Challenge of Climatic Change. Report by Working Party on the Social Dimension of Globalization, Geneva, November. 
JBSED 1,1

International Labour Organization (ILO) (2021), available at: http://www.ilo.org/global/lang-en/index. htm (accessed 9 February).

International Labour Organization (ILO) and International Standards Organization (ISO) (2020), "UNILO and ISO 260000", available at: https://www.learn2improve.nl/iso-26000/about-iso26000/un-ilo-and-iso-26000/ (accessed October 9).

International Standards Organization (ISO) (2020a), "ISO international standards practical tools for addressing climate change", available at: https://www.iso.org/publication/PUB100067.html (accessed October 12).

International Standards Organization (ISO) (2020b), available at: https://www.iso.org/home.html (accessed 12 October).

International Standards Organization (ISO) (2021), available at: https://www.iso.org/iso-9001-qualitymanagement.html (accessed 6 March).

Jensen, J.C. and Berg, C. (2012), "Determinants of traditional sustainability reporting versus integrated reporting. An institutionalist approach", Business Strategy and the Environment, Vol. 21 No. 5, pp. 299-316.

Kanjia, G.K. and Choprab, P.V. (2010), "Corporate social responsibility in a global economy", Total Quality Management, Vol. 21 No. 2, pp. 119-143.

Kottack, C.P. (1999), "The new ecological anthropology", American Anthropologist, Vol. 101 No. 1, pp. 23-35.

KPMG (2021), available at: Corporate-Governance-and-King-III.pdf(assets.kpmg) (accessed 5 March 2021).

Lamberton, G. (2005), "Sustainability accounting-a brief history and conceptual framework", Accounting Forum, Vol. 29 No. 1, pp. 7-26.

Lee, M.K.K. (2019), "Effective green alliances: an analysis of how environmental nongovernmental organizations affect corporate sustainability programs", Corporate Social Responsibility and Environmental Management, Vol. 26 No. 1, pp. 227-237.

Lim, J.S. and Greenwood, C.A. (2017), "Communicating corporate social responsibility (CSR): stakeholder responsiveness and engagement strategy to achieve CSR goals", Public Relations Review, Vol. 43 No. 4, pp. 768-776.

Moratis, L. and Brandt, S. (2017), "Corporate stakeholder responsiveness? Exploring the state and quality of GRI-based stakeholder engagement disclosure of European firms", Corporate Social Responsibility and Environmental Management, Vol. 24 No. 4, pp. 312-325.

Nikolaeva, R. and Bicho, M. (2011), "The role of institutional and reputation factors in the voluntary adoption of corporate social responsibility reporting standards", Academy of Marketing Science Journal, Vol. 39 No. 1, pp. 135-157.

Oizes, G., Moretto, A.M., Moro, M., Rossi, M., Sartor, M., Caniato, F. and Nassimbeni, G. (2020), "The impact of the United Nations Global Compact on firm performance: a longitudinal analysis", International Journal of Production Economics, Vol. 227 September, pp. 1-13.

Perez, A., Lopez, C. and Garcia-Delos Salmones, M.D.M. (2017), "An empirical exploration of the link between reporting to stakeholders and corporate social responsibility reputation in the Spanish context", Accounting, Auditing \& Accountability Journal, Vol. 30 No. 3, pp. 668-698.

Post, C., Rahman, N. and Rubow, E. (2011), “Green governance: boards of directors' composition and environmental corporate social responsibility”, Business and Society, Vol. 50 No. 1, pp. 189-223.

Reid, R. (2013), "Integrated and GRI reporting", NACD Directorship (National Associations of Corporate Directors) March/April, pp. 28-30.

Ringel, L., Hiller, P. and Zietsma, C. (2018), “Toward permeable boundaries of organizations?”, Research in the Sociology of Organizations, Vol. 57 October, pp. 3-28.

Rudel, T.K., Roberts, J.T. and Carmin, J.A. (2011), "Political economy of the environment", Annual Review of Sociology, Vol. 37, pp. 221-238. 
Salvioni, D.M. and Gennari, F. (2016), "Corporate governance and sustainability", Corporate Ownership and Control, Vol. 13 No. 2, pp. 606-614.

Schaltegger, S., Etxeberria, I.A. and Ortas, E. (2017), "Innovating corporate accounting and reporting for sustainability-attributes and challenges", Sustainable Development, Vol. 25 No. 2, pp. 113-122.

Schulz, M. (1998), "Limits to bureaucratic growth: the density dependence of organizational rule births", Administrative Science Quarterly, Vol. 43 No. 4, pp. 845-876.

Serafeim, G. (2015). "Integrated reporting and investor clientele", Journal of Applied Corporate Finance, Vol. 27, No. 2, pp. 34-51.

Sisaye, S. and Birnberg, J.G. (2014), "Sociological approaches of organizational learning: applications to process innovations of management accounting systems", Advances in Management Accounting, Vol. 23, pp. 1-43.

Solomon, J. and Maroun, W. (2012), Integrated Reporting: The Influence of King III on Social, Ethical, and Environmental Reporting, The Association of Chartered Certified Accountants (ACCA), MIMEO, London, August.

Stone, M. (2003), "Is sustainability for development anthropologists?", Human Organization, Vol. 62 No. 2, pp. 93-99.

Summerhays, K. and de Villiers, C. (2012), "Oil company annual report disclosure responses to the 2010 Gulf of Mexico oil spill", Journal of the Asia-Pacific Centre for Environmental Accountability, Vol. 18 No. 2, pp. 103-130.

Sustainability Accounting Standards Board (SASB) (2021), available at: https://www.sasb.org/ (accessed 15 January 2021).

Taliento, M., Favino, C. and Netti, A. (2019), "Impact of environmental, social, and governance information on economic performance: evidence of a corporate 'sustainability advantage' from Europe”, Sustainability, Vol. 11 No. 6, pp. 1-26.

TELLUS Institute (2021), available at: https://www.tellus.org/ (accessed 24 February).

Tho, A.S. (2021), "SASB and IIRC to merge to simplify corporate, sustainability reporting", Financial Management, November 30, available at: https://www.fm-magazine.com/news/2020/nov/sasbiirc-merging-to-simplify-corporate-sustainability-reporting.html (accessed 5 March).

United Nations Global Compact (UNGC) (2020a), “Overview of the UN global Compact”, available at: http://nbis.org/nbisresources/sustainable_development_equity/un_global_compact.pdf (accessed 11 October).

United Nations Global Compact (UNGC) (2020b), available at: https://www.unglobalcompact.org/whatis-gc/mission/principles (accessed 11 October).

United Nations Sustainable Development Goals (UNSDG) (2021), available at: https://sdgs.un.org/ (accessed March 4).

\section{About the author}

Seleshi Sisaye, Ph.D., Ph.D. is a tenured professor of accounting at Duquesne university, Palumbo Donahue school of business. Dr. Sisaye has two earned PhDs: development sociology from Cornell University and accounting from the University of Pittsburgh. His research interests are in sustainability accounting and reporting, sustainable development, accounting innovations and management control systems. He has published several books and numerous peer-reviewed journals in accounting, management and sociology. He has presented papers at national and international conferences and published in their proceedings. Seleshi Sisaye can be contacted at: sisaye@duq.edu

For instructions on how to order reprints of this article, please visit our website:

www.emeraldgrouppublishing.com/licensing/reprints.htm

Or contact us for further details: permissions@emeraldinsight.com 